\title{
IV. On the use of an iodine voltameter for the measurement of small currents
}

\section{E. F. Herroun F.I.C.}

To cite this article: E. F. Herroun F.I.C. (1895) IV. On the use of an iodine voltameter for the measurement of small currents, Philosophical Magazine Series 5, 40:242, 91-94, DOI: $10.1080 / 14786449508620711$

To link to this article: http://dx.doi.org/10.1080/14786449508620711

曲 Published online: 08 May 2009.

Submit your article to this journal $[\pi$

Џ Article views: 4

Q View related articles $₫$ 
IV. On the Use of an Iodine Voltameter for the Measurenient of Small Currents. By E. F. Herroun, F.I.C., Professor of Natural Philosophy, Queen's College, London*.

$T^{H E}$ instruments in general use for the direct measure1 ment of currents by electrolysis, as in the determination of reduction factors of galvanometers, comprise the hydrogen, silver, and copper voltameters : each of these possesses certain advantages, but none is free from defect. When occasion arises to make a large number of determinations of relatively small currents, the difficulties attending their use become more manifest.

Some of the defects of the ordinary types may be briefly stated. The hydrogen voltameter, consisting of platinum plates immersed in dilnte sulphuric acid, has the following disadvantages :-

1. It acquires a large counter electromotive force of polirization, so that the current, on first joining up, is very inconstant.

2. Its internal resistance is subject to considerable fluctuations, according to the rate and mode of disengagement of the electrolytic gases.

3. Oxygen present in the dilute acid, or migrating from the anode, diminishes the amount of hydrogen collected, and so causes the current to be underestimated.

4. When small currents are being measured, the bubbles which cling to the electrodes or sides of the graduated tube cause an appreciable error.

5. Calculation of the current-strength is rendered difficult owing to the necessity for correcting the volume of gas for temperature, barometric pressure, and for the tension of vapour of the dilute acid employed, which last is frequently not exactly known.

In the silver voltameter the foregoing objections do not hold, with the exception of No. 3 ; for dissolved oxygen has been found to affect the yield of silver, a greater amount being obtained when the electrolysis is conducted in vacuo or hydrogen than in air. But in the silver voltameter the experimental difficulties in washing, drying, and weighing, it may be only a few centigrammes of silver, involve a large expenditure of time; or if the weight of deposited silver be increased by prolonging the current, the difficulty of maintaining it constant is greater.

The difficulties which exist with silver are still more

* Communicated by the Physical Society : read May 10, 1895. 
apparent with copper; for, as its chemical equivalent is much smaller, the weight of copper yielded by a given number of coulombs is only $\frac{31.75}{108}$ of the weight of silver. In addition, its greater readiness to oxidize may cause the deposit of copper to become superficially oxidized in the process of washing and drying. This, however, may partly compensate for the defect in weight due to dissolved oxygen round the kathode.

If a list of the electrochemical equivalents of elements be examined, next to mercurous mercury, the one which has the highest value will be found to be iodine; and it is curious that, although the liberation of iodine from potassic iodide was very early used to detect electric currents, no attempt in recent years seems to have been made to utilize it for quantitative measurements.

As iodine is an anion, dissolved oxygen, which diminishes the yield at the kathode in other voltameters, will have no such action in a neutral solution of iodide ; and as its colour reaction with stareh is extremely sharp, and its titration with standard sodium thiosulphate a process of greater accuracy than the performance of the average balance, the exact determination of the amount of iodine liberated by a current is both easy and rapid.

\section{Experimental Details.}

A voltameter consisting of platinum plates in a solution of potassic iodide is not suited for quantitative measurement; as, upon electrolysis, it yields caustic potash and hydrogen at the kathode, the former of which by diffusion would come in contact with the iodine set free at the anode, converting it into iodide and iodate. If this were all it would be easy to acidify after electrolysis, when the iodine would be again set free; but there is besides the additional disadvantage, that a rather large electromotive force of polarization is set up between the electrode surrounded by hydrogen and $\mathrm{KOH}$ and the one surrounded by iodine.

The solution actually employed was a 10 per cent. to 15 per cent. solution of neutral zinc iodide (a solution that keeps well if a small strip of zinc be suspended in it). The anode was a plate or disk of platinum placed at the bottom of a tall narrow beaker and joined by a platinum wire, sealed through a glass tube extending beyond the top of the beaker, to the outside circuit. In this way all the iodine is liberated at the bottom of the column of liquid, and, owing to its high density, 
tends very little to diffuse upward. The kathode was a rod of amalgamated zinc, loosely jacketed with filter-paper or linen. The zine rod should be supported so that it only dips a few centimetres into the top of the liquid, thus diminishing the liability of any of the liberated iodine coming in contact with it. The jacketing was found necessary to prevent particles of electro-deposited zinc becoming detached and falling into the solution of iodine at the bottom of the cell.

When used with currents not exceeding $\frac{1}{20}$ of an ampere and an anode of 9 square centimetres, it was found that no iodine diffused up to the level of the kathode in experiments of over an hour's duration, the cell being kept completely at rest. With feebler currents, lasting for a protracted time, it was found advisable to use a U-tube with a good plug of asbestos in the bend, filled with the zinc-iodide solution and having a platinum plate and zinc rod in the two sides of the tube ; but naturally with this form the resistance was much greater than with the beaker form.

With large currents " electric convection" leads to diffusion of the iodine through the whole liquid, and therefore the author does not consider it well adapted for their measurement, except for approximate, rapid determinations.

In the Report to the Board of Trade of the Electrical Standards Committee, the importance is pointed out, in using a silver voltameter, of having a considerable vire-resistance in the circuit to mitigate the effect of change of resistance in the voltameter itself: the same precautions apply to the iodine voltameter and a slight readjustment of the resistance at first employed is usually necessary to keep the current, as indicated by a galvanometer, constant. 'This is owing to a small change in the adverse electromotive force,-but if a battery of fairly high E.M.F. (ex. gr. 3 (trove cells) be employed, controlled by a moderately large resistance, the current may be kept very constant.

After the iodine voltameter has been in circuit for a time which will vary with the degreo of accuracy required and the actual strength of the current, the latter is stopped and the zinc kathode is immediately removed from the liquid. The solution is then stirred up, and the amount of free iodine determined by direct titration with standard sodium thiosulphate solution, after the addition of starch. Taking the electrochemical equivalent of iodine as 001314 grm. per coulomb, a convenient strength of sodium thiosulphate solution is one of which each cubic centimetre reduces five times this amount $(1 \mathrm{cub}$. centim. $=\cdot 00657 \mathrm{grm}$. I) : this corre- 
94 Todine Voltameter for the Measurement of Snall Currents.

sponds to a solution containing 12.815 grms. of pure sodium thiosulphate per litre; but it is necessary to standardize it from time to time with a standard solution of iodine, as its value is liable to change somewhat on keeping.

As pure zinc iodide is not always readily obtainable, though it can be easily prepared, the anthor has found that a solution of 15 per cent. zine chloride, to which about 5 per cent. potassic iodide has been added, may be substituted for pure zinc iodide. Any chlorine, even if liberated, which is improbable with small current-densities, would at once yield its equivalent in iodine without escaping, and should any caustic potash form at the kathode it would merely produce zinc hydrate and potassic chloride.

A single example of the accuracy and rapidity of the method, selected from laboratory notes, may here be given :-

" Dec. 19, 1894.-Current through calibrated galvanometer $=20^{\circ}$.

Time current was passing $=2$ hours.

Weight of silver deposited $=0.2122 \mathrm{grm}$.

Current (from above deposit) $=0.0264$ ampere.

The same deflexion $\left(20^{\circ}\right)$ obtained using iodine voltaneter. Time $=30$ minutes.

Iodine liberated required $9 \cdot 6$ cub. centim. of standard thiosul-

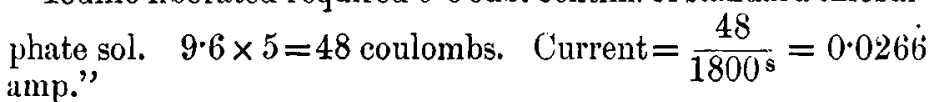

'The latter result is seen to be in fairly close agreement with that obtained with the silver voltameter, but slightly higher, as was to be expected from the reasons stated above. It will be noticed that the duration of the experiment was only a quarter of that with the silver voltameter.

In conclusion the points which recommend the iodine voltameter in the author's opinion are as follows:-

1. Its freedom from the effect of dissolved oxygen which gives "low" results with kationic voltameters.

2. The relatively short duration of the current necessary to obtain results of fair accuracy.

3 . The rapidity of the volumetric estimation of the liberated iodine.

4. The ease and rapidity in calculating the results. 